\title{
A Gramscian Approach to Studying the Judicial Decision-Making Process
}

\author{
Pablo Ciocchini ${ }^{1} \cdot$ Stefanie Khoury $^{2}$
}

Published online: 24 October 2017

(C) The Author(s) 2017. This article is an open access publication

\begin{abstract}
This paper applies a Gramscian analytical framework to scrutinise the judicial decision-making process. Based on two distinct research projects, the article explores how, on one hand judges in criminal courts can be identified as part of the bureaucratic machinery of the state, as 'technicians of repression'; whereas, on the other hand, human rights judges can be distinguished as providing 'moral and intellectual leadership' in their production and reproduction of certain values. Some of the key questions this article seeks to answer are: What is the role of hegemony in the judicial decision-making process? To what extent are legal actors both 'technicians of repression' and 'moral and intellectual leaders'? This paper uses examples from empirical research conducted at courts in Argentina and at the European and Inter-American Courts of Human Rights to identify and explore this dual role of judges as both repressive technicians and moral and intellectual leaders in neo-liberal capitalist societies.
\end{abstract}

\section{Introduction}

This article proposes a Gramscian analytical framework to scrutinise the functional role of courts and judicial actors in the production and maintenance of a hegemonic project. It argues that a Gramscian framework provides a critical understanding of the role of judicial actors in society by teasing out the internal contradictions of the judicial decision-making process and, more specifically, by scrutinising how intra- and inter-class contradictions

Technicians of repression-Many thanks to Dave Whyte for this observation.

Stefanie Khoury

Stefanie.Khoury@liverpool.ac.uk

Pablo Ciocchini

P.Ciocchini@liverpool.ac.uk

1 University of Liverpool in Singapore, 29B Tampines Ave. 1, \#03-02, Singapore 528694, Singapore

2 Department of Sociology, Social Policy and Criminology, School of Law and Social Justice, University of Liverpool, Eleanor Rathbone Building, Bedford Street South, Liverpool L69 7ZA, UK 
play out within a larger social context. The article notes that those contradictions veil a class bias within the law, but it argues that contrary to some earlier Marxist work (see for example Quinney 1980), the advantage of a Gramscian approach is that it does not reduce the law to an instrumentalist base/superstructure understanding. Rather, building upon Hall et al.'s (1978) work on the role of judges in the production of hegemony, this article argues that judges play a dual role in our societies as both 'technicians of repression'-actors of the bureaucratic machinery of the state-and 'moral and intellectual leaders' - actors who produce and legitimate the values of the dominant social order.

Throughout the 1970s and 1980s there were lively debates that inspired a range of analyses and critiques of ideology and hegemony. Since roughly 1990, however, the place of ideology, and interest in it as a concept, has subsided. The concept of hegemony, on the other hand, remains much more significant across a variety of disciplines including international relations, international political economy, sociology and criminology (e.g. Cox 1983; Bieler and Morton 2014; Cutler 2005; Litowitz 2000). Gramsci's (1971, p. 12) definition of hegemony, “(...) includes firstly the 'spontaneous' consent given by the great masses of the population and secondly the apparatus of state coercive power which 'legally' enforces discipline on those groups who do not 'consent' either actively or passively". In other words, hegemony is the ability to infuse the values of the dominant social group into the minds and everyday lives of subaltern groups so as to achieve their spontaneous consent. Hegemony is achieved when these subaltern groups consider those values (and practices) to be in their interests, even though in practice the values of the dominant social group work against them. We argue that the concept of hegemony informs a critical analysis of the judicial decision-making process precisely because courts are arenas within which diverse struggles play out. Dominic Strinati (1995, p. 165) describes 'spontaneous consent' as being negotiated through the construction of a political and ideological consensus which incorporates both dominant and dominated groups. To the best of our knowledge, there are no studies that apply Gramsci to inquiries into the judicial decisionmaking process. ${ }^{1}$ Our discussion here seeks to fill this gap by developing a framework for examining the system-preserving and system-reproducing capacities of courts.

\section{In Search of an Analytical Framework}

Earlier Marxist approaches to law, including the work of Quinney (1980), took an instrumentalist approach and resulted in a focus on law enforcement agencies and the law itself rather than of the role played by judges and courts. This approach was followed by more complex understandings of law, such as Chambliss' analysis that law is not merely an instrument of the ruling class, but a result of the tensions produced by class struggle. Chambliss' argument centred upon the tensions between social forces outside the juridical realm and the broader internal contradictions of the system that create the necessity for legal institutions. By so doing, he conceptualised judges and courts' roles as reactionary: as responses to those tensions (1993, pp. 29-30). In an earlier work, Chambliss and Seidman (1971) analysed different extra legal factors that influenced courts' decisions. However, their analysis centred upon demonstrating the fallacy behind the idea of law and the neutrality of courts rather than analysing the active intervention of judges in society. In Hall et al.'s (1978) seminal piece they looked at the central role that judges play in the

\footnotetext{
${ }^{1}$ For a related but distinct discussion of a Gramscian approach within Critical Legal Studies see Kennedy (1982a).
} 
production of hegemony. According to the authors, judges contribute to the establishment of hegemony through their "judicial response to crime" (Ibid., pp. 30-31). Following Hall et al., this article develops an analytical framework with which to examine the role of hegemony but with a focus upon the judicial decision-making process. We do so by considering the extent to which judicial actors are both 'technicians of repression' and 'moral and intellectual leaders'.

Law can be understood as a technique for the organisation of hegemony in and through the state, producing consent among the dominated classes at the same time as it organises the administration of public force (Buckel 2011). Judges play a crucial role in capitalist societies by interpreting and enforcing the law in ways, as our examples below suggest, that help to uphold the dominant system. The novelty of applying a Gramscian perspective to the analysis of the judicial decision-making process is two-fold. Firstly, this analysis reveals that as judges enforce the law, they act as legal 'technicians', applying officially recognised interpretations of the law. Their role is to reproduce and conserve the status quo. But judges can also occupy a leadership role by promoting certain moral values. They do this by expanding, and in some cases even subverting, traditional legal concepts.

Gramscian theorists have not tended to explore the moral and intellectual leadership provided in statements and pronouncements of state technicians and state functionaries, such as judges. Indeed, Gramsci himself never fully developed the idea of judges as 'moral and intellectual leaders', as opposed to other actors such as the clergy, unionists, educators, or politicians. However, judges play a decisive role in introducing certain issues into the social imaginary by considering them to be social problems worthy of being played out in the legal sphere. In this role, judges effectuate a decision of moral standing by identifying and deciding upon the conflicts in society. These decisions also contribute to the definitions of 'political' issues and the recognition of 'legal' issues, reproducing the idea that these spheres are separate and distinct. In this way, the judicial decision-making process contributes to producing intra-class consensus, but also inter-class consent for the dominant social order that profits from this fake separation.

Below we draw upon our experiences during two separate research projects carried out between 2009 and 2013. One project analysed court delay in the Province of Buenos Aires (PBA), Argentina using participant observation and interviews (Ciocchini 2013); the other scrutinised mechanisms of corporate accountability at the European (ECtHR) and InterAmerican (IACtHR) Courts of Human Rights through case-law analysis and interviews (Khoury 2014). There were important differences between the projects, e.g. one was set in the national context, the other in the international; one dealt with criminal justice, the other with human rights. These differences led us to consider how the judicial level and context within which judges operate impact upon their role as either cogs in the bureaucratic machinery, as Ciocchini's (2013) findings indicated, or as leaders able to draw out consent from the masses, as were the findings of Khoury's (2014) research. The results from these independent projects raised questions about the role of courts as both coercive institutions representing the force of the state, and hegemonic institutions that produce consent for particular social relations. Identifying judicial decisions as always both oppressive and common sense led us to scrutinise the different roles of judges as 'technicians of oppression', but also as 'moral and intellectual leaders' capable of producing consent.

The researches indicated similar results regarding their analyses of the role that judicial actors play in the context of neo-liberal capitalism. Following Brown (2003), neo-liberalism is here defined as more than the simple "repudiation of Keynesian welfare state economics and the ascendance of the Chicago School of political economy". Rather, neoliberalism is a political rationality that "involves extending and disseminating market 
values to all institutions and social action" (Ibid., 2003). Ciocchini's (2013) research explored the development of a neo-liberal managerial rationality that favoured a punitive stance within judicial reforms otherwise meant to improve due process within the PBA's criminal courts. The research was based on an analysis of data derived from forty-five indepth interviews with key informants and court observations conducted in 2010. Ciocchini found that a Gramscian analytical framework was able to illuminate the contradictions between judicial actors' critical perspective on the police and the managerial reforms that promoted a punitive response to crime and their reproduction of institutionally accepted practices that empowered police and focused on the repression of street crimes. At the same time, applying a Gramscian approach made it possible to understand this punitive response as a loss of 'leadership' for judges in criminal courts. As a result of the political manipulation of crime, judges in the PBA have became the target of politicians and the media, and their role has been increasingly reduced to that of 'technicians of repression'. Managerialism has been a strategy to re-legitimise criminal courts, not by empowering judges, but instead by indirectly reducing their discretional power through increasingly stricter performance evaluations.

Khoury's (2014) research examined the lack of corporate accountability in the regional human rights systems. Nine judges from the ECtHR and six from the IACtHR (including one former judge) were interviewed in 2010. Khoury sought to gain insight into judicial perspectives on the failure of human rights to address corporate violations of human rights and situate them within the context of the global political economy. Her analysis further sought to understand the role human rights judges play in producing hegemony. She explored the power relations at play regarding struggles in and around courts pertaining to issues of corporate accountability. Her findings led her to consider how Gramsci's insight into diffuse power relations - as opposed to the orthodox Marxist position of the centralisation of power in the coercive mechanisms of the state-could be applied to develop a framework to analyse the judicial decision-making process. Her research led her to identify the role of judicial actors as 'moral and intellectual leaders' who construct hegemony through the judicial decision-making process.

Both research findings coincided with the critical perspective that judicial actors can never really be 'neutral', revealing the ideological perspectives of the respondents and calling attention to the fact that the law itself must be considered within its social, economic, and political context (Hunt 1993). Notwithstanding, the analyses found, as we explore below, that it was misleading to interpret the judicial actors' perspectives as the result of individual preferences. Rather the diversity within the perspectives of the judicial actors could be better understood when interpreted as expressing contradictions inside the hegemonic project. Thus, whilst judges reproduce and legitimate the values of the dominant social order, they may not necessarily be fully conscious of that role. Judges are rather socialised into the dominant hegemonic project. One aspect of this socialisation is a particular class affiliation that can be reflected in judicial values and ideas. But, perhaps more decisive to an understanding of judicial behaviour is legal education. Numerous studies have demonstrated a heavily ideological bias in law schools that influences legal professionals towards an understanding of law as autonomous of social power dynamics (Kennedy 1982b; Granfield 1986; Stanley 1988).

The class affiliation of judicial actors refers to the position in the social division of labour inside the state. Thus, judicial actors in supranational courts will have a different class affiliation than judicial actors in lower courts and therefore will reflect different contradictions and divisions (Poulantzas 2000, p. 154). The former has a bourgeois class affiliation, as reflected in their career backgrounds with many judges coming from high 
governmental positions (not uncommon with diplomatic careers), or from other international courts (Voeten 2007) and will reflect intra-class contradictions within the power bloc. The latter can be affiliated with the petty-bourgeois class (most judges in lower courts start as interns while they are studying law at the university, moving from the lower to the higher ranks in the judicial institution before being appointed as judges (Sarrabayrouse 2004). Judges from lower courts will more likely be affected by inter-class contradictions between the dominant class and occasional alliances between the working class and the petty-bourgeoisie (Ibid., p. 155). Poulantzas (2008) pointed out in regards to state personnel that, on one hand, judicial actors hold a class position, but are not a separate social group. On the other hand, 'state personnel',

...constitutes a specific social category, possessing, across its class divisions, its own unity, because of the organizational framework of the capitalist state apparatus (separation of the state and the economy) and because of its relative autonomy from the dominant classes (Ibid., p. 313).

It is therefore important to identify the relation of forces in each case in order to better understand the judicial outcome. These relations of forces explain contradictions inside judicial institutions. In Ciocchini's (2013) research, these contradictions were manifested as an ideological struggle between punitive judges and prosecutors, and more liberal ones. Whereas in Khoury's (2014) research, respondents struggled with their role as judges 'applying law' (even in cases where they did not necessarily agree with it) or 'creating law' when they deemed it necessary. In both researches the respondents located the problem outside of the juridical realm, in the sphere of the political.

\section{Judges as Technicians of Repression}

In the case of the criminal courts in the PBA, the role of judges cannot be understood without taking into consideration the consequences of the neoliberal turn that took place after the transition to democracy in the mid-1980s. Neoliberalism promoted an unbridled capitalism that exacerbated social inequality and resulted in a severe increase in the crime rate. From the 1990s onwards, the political agenda has been marked by 'the crime problem' and the media has consistently fuelled the fear of crime. As a consequence, the police and criminal courts have been widely discredited. The media depicts both police and judges as corrupt. Criticisms of the police have focused on their ineptitude to prevent and investigate crime, whereas criticisms of judges have focused on what is considered a liberal ideology driving them to release 'dangerous' criminals on technicalities or deliver lenient sentences.

The contradictions that cross through the state are materialised in criminal courts as a tension between the rule of law and popular punitivism. This tension is evidence that the institution is not monolithic, and that there is a constant tension inside between 'progressive' judges and 'conservative' judges who support a tough-on-crime approach. This tension plays out as a criticism of the function that the criminal justice system plays in a given society. In the PBA, the criminal justice system is seen from within its own ranks as one that "... deals with cases where defendants are caught red-handed. ... [With] 50 sentences of an idiot handcuffed by the police for every one of a white-collar crime, if you're lucky!". ${ }^{2}$ Moreover, there is a pressure to pursue certain 'crimes' because as one

${ }^{2}$ All quotes by Ciocchini 2013 were conducted in Spanish; translation by authors. 
respondent put it "... you put your future at risk [when you pursue white-collar crime] because you make powerful enemies. So it's better to keep handcuffing the [punks]" (Prosecutor 2). The recognition of the political and personal backlash of trying to use the justice system for non-traditional crimes is one that points to the class bias of the system. As one respondent put it,

The penal system removes the conflict. It's done. ...It doesn't exist anymore. Once the [judge] take[s] a decision, it's done; the lad is already in prison, the social demand has calmed down, the pressure in the media has finished. ... The [judge] sentence[s] when no one cares anymore (Judge 1).

These judges and judicial actors are generally labelled by the media and politicians as "garantistas", i.e. those whose main role is to guarantee constitutional rights. There is a tension between classes and fractions that is reflected in the tension within the judicial institution between the liberal 'garantistas' judges and more conservative judges, and prosecutors who openly support tough-on-crime policies. These 'conservative' judges explicitly argue that law should be interpreted to enable a more punitive outcome, despite the original intention of the legislators. As an example of this attitude, a judge explained how the existing legislation did not differentiate between time spent in pre-trial and home detention and so at the sentencing trial she would not consider the latter as time already served (Judge 4).

Poulantzas' (2000, p. 129) abovementioned characterisation of the state is therefore instructive if we adapt it to the courts, because it provides a means to understand courts as "the specific material condensation of the relationship of forces among classes and class fractions", reflecting the different correlation of forces at any given time. In the example of the PBA, conservative judicial actors seek to defend a tough-on-crime approach. They do this by the following schema:

When the crime is serious it goes to trial. ... [Otherwise] ... we apply a progressive process of coercion, for example with petty crimes we file the case. Then our options are probation, plea-bargaining with suspended sentence or prison sentence. ... A first-time offender, let's say for simple theft, who pleads guilty - to reach an agreement and be released - is really trying to avoid a prison sentence. [If he is given a prison sentence] the next time he is detained, he will not be released [but rather] sentenced to prison as a repeat offender. This is 'the process of building a penalty by the public prosecutor' that seeks to overcome the leniency of criminal law (Prosecutor 3).

The power of the prosecutor and the judge in 'building a penalty' is evidence of the power they have as law's interpreters. During the interviews, the 'liberal' judges recognised the bias of the criminal justice system against the most vulnerable sectors of society, however these same judges rejected the possibility of making any change to the system. They argued that they were powerless to make any significant changes because they are servants to the law and do not decide what cases are brought to the courts but rather are forced to deal with issues selected by the police and prosecutors. However, this argumentation reifies law by treating it as an abstract thing that exists in its own dimension rather than as an expression of social relations that are constantly deconstructing and reconstructing the law in order to produce a particular social order. In the current context of the PBA, the perceived powerlessness of these judges points to the loss of leadership by judges in criminal courts and their reduction to technicians of repression. Judges used to play a lead role directing investigations and so were able to impose their own criteria upon the police. 
In recent years, their role has been reduced to granting or denying the prosecutor's request; combined with the intense pressure judges receive from politicians and the media, they have lost their de facto autonomy and their role, in practice, has been redefined as one of the technical control of the legality of the punitive decisions taken by police.

This loss of leadership can be interpreted as the result of a shift away from penal welfarism to popular punitivism with a distrust of penal experts (Garland 2001; Pratt 2007). The focus is on a more emotional punitive discourse that finds legal protections as obstacles to achieve justice. Whilst, this is a trend that has been widely explored in central societies, such as the US and the UK (Ibid.), it has very different expressions in semiperipheral societies, such as Argentina. Whilst fear of crime is pervasive in both cases, in the former the actual crime rate has been reduced (Levitt 2004), whilst in the latter it has dramatically increased (Carrington et al. 2016, p. 7). Related to this phenomenon is that in the US and UK, police and courts enjoy high levels of confidence (Indermaur and Roberts 2009), whilst the opposite is true in the PBA (Oyanedel 2016). Nevertheless, a 'disempowering' of judges is common in all of these cases: in the US mandatory minimum sentences and mandatory guidelines have removed power from judges (Simon 2007, p. 128), whilst in the PBA this has been achieved by changes in the legislation that have increased minimum sentences and restricted parole, among other measures.

Two other significant elements have promoted the process that reduces judges to 'technicians of repression': the fear of suddenly become a media target, political defamy because of judicial leniency (Kostewein 2015), and the imposition of a managerial rationality to close cases swiftly (Ciocchini 2014). Both elements should be read with caution, because on the one hand, as Kostewein (Ibid.) has indicated, reports by the press on the criminal justice system are not homogenous; in some cases they support a more critical approach to punishment, and in some cases judges 'use' the press as a pretext to justify their own ideological decisions. On the other hand, Ciocchini (Ibid.) points out that judges have managed to partially neutralise some managerial pressures. However, the combination of these two aspects, and the legislative changes mentioned above, have increasingly forced judges to take a punitive stance, confirmed by one prosecutor:

Society has lost respect for judges, prosecutors and public attorneys ... today society quarrels againt every decision [judicial actors make]. What they say is no longer holy word. Not to mention the media! They are the first to judge you whenever you decide the case in a way that was not what society was expecting you to do ... (Public prosecutor 7).

To address the severe lack of public confidence, criminal courts have come under a process of performance improvement reforms. This process assumes that the crisis of legitimacy is due to the courts inefficiency. Furthermore, it also assumes that more efficiency will more effectively punish crime, which will make people feel safe; and at the same time, more efficiency will result in faster and fairer cases for defendants.

Whilst the managerial rationality has not yet measured judges' performances in terms of sentencing, it has forced them to focus their efforts on street crimes, and to promote pleabargaining and other mechanisms that in practice result in a lack of cross-examination of the evidence gathered by the police. Under managerialism, adversarialism-the confrontation between the prosecutor and the defendant before a judge-is slowly dissolved and replaced by an administrative perspective that focuses on the standardisation of case disposal and the maximisation of system efficiency.

A paradoxical result of the relevance that the crime phenomena has acquired in semiperipheral societies has been a loss of leadership of criminal judges. Managerialism and 
penal punitiveness turn criminal judges into mere 'technicians of repression' in the local context of the PBA. In another context, supra-national court judges have gained immense powers and prestige. Thus, in contrast with judges in local criminal courts, human rights judges have been gaining leadership over the past few decades. These judges have played a decisive role in guaranteeing intra-class hegemony. At the same time, their judgments have produced 'common sense', leading to inter-class consent.

\section{Judges as 'Moral and Intellectual Leaders'}

One of Gramsci's (1971) major themes was a discussion of two types of intellectuals, which he based upon class origins. He (Ibid., p. 7) defined 'traditional intellectuals' as those who represent a "historical continuity uninterrupted even by the most complicated and radical changes in political and social forms", such as the clergy. These "traditional intellectuals' regard themselves as autonomous and independent from the dominant social group. 'Organic intellectuals', on the other hand, are rooted in capitalism and serve the classes of that system, i.e. working class and bourgeois. Gramsci reasoned that one of the most important characteristics of any group contending for dominance is its struggle to ideologically assimilate and conquer the traditional intellectuals. However, he noted that "this assimilation and conquest is made quicker and more efficacious the more the group in question succeeds in simultaneously elaborating its own organic intellectuals" (Ibid., p. 10). Judges can be identified as 'organic intellectuals' given their intellectual function and capability to construct a model of social and political consciousness. As organic intellectuals, judges influence politics, public discourse and promote certain forms of common sense through judgments. Thus, when a judgment finds legislation to be contrary to upholding democratic values, for example, the judge relies upon her interpretation of the law and necessarily draws upon her own values in making that judgment. In this way, the judge uses her personal moral compass to evaluate legislation that will impact upon the wider population and move social norms toward a particular direction.

Gramsci did not identify judges as either traditional or organic intellectuals. We consider that judges can be both 'traditional intellectuals', who self-identify as autonomous and independent of the dominant social group (Ibid., p. 7), and 'organic intellectuals', who internalise particular values that uphold the capitalist system, and then produce and reproduce those values in their judgments. This dual functionality means that judges can serve a particularly important role in the hegemonic project because the illusion of the neutrality of the traditional intellectual allows judges to carry out an ideological project within civil society (as opposed to political society), despite their work remaining highly political. Indeed, the impartiality of judges is a "myth" that has been well-demonstrated (Fitzpatrick 1992; Carlen 1976; Feeley 1992; Harrington and Yngvesson 1990; Yngvesson 1985).

Central to the achievement of moral and political leadership is the creation of a common worldview that responds to the needs of social and economic reproduction (Jessop 1990, p. 51). This common worldview is created, in part, through a complex system of ideological apparatuses, which for Gramsci (1971) are the Church, trade unions, schools, mass media, (political) parties, but also through the pervasive role of intellectuals. According to Gramsci (Ibid., pp. 195-196),

... [the] juridical problem is a problem of education of the masses. This is precisely the function of the law in the State and in society; through 'law' the State renders the ruling group 'homogenous', and tends to create a social conformism which is useful 
to the ruling group's line of development. ...The general activity of law...involve[s] directing civil society, in those zones which the technicians of law call legally neutral - i.e. in morality and in custom generally.

Gramsci's central insight and contribution to Marxism was that force alone is not enough to maintain the power of a particular social group. Consent is achieved in part by the "moral and intellectual leaders" who embed dominant values into the day to day lives of the people. This leadership is two-fold: it achieves consensus within the power bloc, i.e. among the factions of the dominant class, and it also normalises certain values and rules so that the ideology of the dominant group becomes the ideology of the masses.

National supreme or constitutional judges, as well as supra-national and international judges, exert intellectual and moral leadership by imposing their legal interpretations to subordinate judiciaries. The effect is that the decisions of these judges in turn shape policies, and more broadly political discussions over those policies (Wasserfallen 2010). An example of the political relevance of these high-court judges is the recent declarations by Theresa May, the UK's prime minister, who argued that one of the key reasons to leave the EU was to withdraw from the jurisdiction of the ECtHR (Asthana and Mason 2017). The UK's Lord Hoffman, for example, has continuously berated the ECtHR for being overly political claiming "a judicial body was not entitled to introduce new concepts, such as the protection of the environment, into an international treaty which made no mention of them 'simply because it would be more in accordance with the spirit of the times" (N/A 2009). The harsh criticism of the ECtHR may be because its decisions do impact upon the values of the member states. The Strasbourg judges therefore have a particularly powerful leadership role that extends to moulding the values of the member states which are obligated to integrate ECtHR decisions into their legal systems. Indeed, it is generally accepted that in liberal democracies judges ought to apply the law in ways that reflect the evolving moral and ethical standards of a society (Edwards $v$ Canada (Attorney General) 1930; Loucaides 2007; Terris et al. 2007, p. 26). It is in the power to decide the legal-and moral-direction society takes that judges play a vital function in the production of consent. Whether consent is achieved or not is a different issue, since counter-hegemonic struggles can be played out in the rejections and challenges to laws and judicial decisions.

High-court judges exert moral and intellectual leadership by shaping society's larger 'common sense' view by making high-impact decisions in areas such as the state's legitimate use of power (e.g. prisoners' rights, stop and search powers, use of torture, etc.), concepts of life and death (e.g. abortion, capital punishment, euthanasia, etc.), gender diversity recognition (e.g. LGBTQ rights), property and labour rights. Their leading cases are widely reported by the media, publicly discussed by politicians, and publicly denounced or supported by activists and NGOs. The US Supreme Court's decision in Brown v. Board of Education (1954) is an example of the social impact these judges can impose.

The increasingly political role of judges has been identified as the process of the 'judicialization of politics' (Santos 2002, pp. 335-342). The dominance of neo-liberal capitalism on a global scale since 1990 has had a major impact upon the legal sphere, particularly visible by a growing reliance on courts and the judiciary in the articulation and determination of core political and economic issues. Judges are called upon to handle a range of social, economic or political issues resulting in the absorption of social and political conflicts into the juridical sphere. But the effect of judges taking on a political role is rather that these conflicts are depoliticised, in an attempt to neutralise social unrest by channelling conflict through the so-called legitimate and 'neutral' forum of the courts. 
These issues include public policies related to labour, criminal and social justice, the environment, property, trade and commerce, education, immigration, equality, etc. (Hirschl 2004, 2008, 2011). This process has lead to a displacement of conflict otherwise arising from political decisions, but now playing out in the courts.

The accrued social and political visibility and importance of the judiciary in the post-Cold War landscape has given it a significant role in the production, reproduction and diffusion of the dominant values of neoliberal capitalism, and particularly in its protection of private property. Khoury's (2014) research illustrated that international human rights law is one of those legal disciplines, where the protection of private property has been the basis for extending human rights to corporations. By doing this, judges lead the dominant factions of the ruling class and create consensus within the power bloc. In the case of human rights law, the developments at the ECtHR have had the effect of moving beyond the 'human right to property' by granting rights to the entity that embodies property: the corporation-an institutional form of property in which the aggregate capital of shares is represented by individual shareholders. At the IACtHR, it is the shareholders' human rights that are protected by the Convention, but this amounts to two things: firstly, the corporation gains protections vicariously through its shareholders (for a discussion see Khoury and Whyte 2017, pp. 136-155); and secondly, the shareholder remains completely "legally immune" (Glasbeek 2005) from any kind of responsibility for corporate violations of human rights. The interpretations of the law that led to this 'immunity' are made by human rights judges. In one defence of this logic, a respondent from the IACtHR suggested that "...there is [no] way to consider the shareholders responsible for [corporate] violations [of human rights]" (IACtJ 1). Although there is nothing in the law per se that prevents shareholder responsibility. Rather increasingly the InterAmerican human rights system is moving its case law, through judicial interpretation, towards business-friendly outcomes by recognising the rights of corporations vicariously through the shareholders (see for example Gabriela Perozo et al. v Venezuela, 2009; for a discussion see Khoury 2014, Khoury and Whyte 2017).

Judicial decisions are also 'common sense', meaning that whilst courts and judges are influenced by material reality, the power of a judgment lies in its taken-for-granted standing. Gramsci (1971, p. 419) explained that:

[Common sense] takes countless different forms. Its most fundamental characteristic is that it is a conception which, even in the brain of one individual, is fragmentary, incoherent and inconsequential, in conformity with the social and cultural position of those masses whose philosophy it is.

In the courts, the contradictions and inherent inequalities of capitalism are mediated and refracted through the attitudes and behaviours of judicial actors that produce and reproduce a common sense understanding of law and society. Legal common sense is one that is necessarily defined by its heterogeneousness, falling squarely within Gramsci's definition. It is this diversity that makes it possible to establish consent to ruling class attitudes and interests by its internalisation within the judiciary and beyond it. Judicial decisions taken at the human rights courts impact upon national legislations. They are disseminated by the media and inform political debates. Even whilst the wider public may not be aware of a particular decision, the influence that it may have upon everyday lives is not negligible. For example, the ECtHR has played a key role in developing societal acceptance for certain controversial issues such as medically assisted procreation (IVF) for same-sex couples. ${ }^{3}$

3 See for example Charron et Merle-Montet v France (2015) and the subsequent 2017 ethics decision that
led the French government grant lesbian couples and single mothers the right to medically assisted 
Judicial opinions either reflect a society's common sense view at a specific historical moment (e.g. the living tree approach) or mark the influence of the judiciary on creating a common sense view of a particular kind (e.g. when the judiciary imposes or 'leads' society toward accepting a particular value). Because human rights judges are invested with authority and prestige, their decisions can set the official narrative that leads to the adoption of values which inform political agendas, future judicial decisions and more generally become part of our everyday values.

But the values that we are 'led' to accept are not always those that grant a fair protection or necessarily uphold human dignity, as Claire Cutler (2005, p. 539) has argued, one aspect of law is that it conceals that it is first and foremost the protection of regimes of private accumulation that are being safeguarded through judicial decision-making. Judges uphold hegemonic concepts such as property but this is done in a way that seeks to transmit the value of 'equality' by promoting a public perception that the protection of property provides protection for all. At the ECtHR, for example, the principle of 'equality' is a means to justify the protection of the human rights of corporations:

...corporations as legal persons have access to the ECHR, like physical persons. ...I think human rights are for everyone, not just the weak [but] they [corporations] deserve the same protection as everyone else. ...We [the judges] don't look at the person, but at the case and its merit" (ECtJ9, emphasis added).

[Corporations before the ECtHR]...is just. It is because the individual needs protection...individuals need tribunals like ours. It is [because] of their [corporation's] inferiority vis-à-vis the state (ECtJ4).

... 99\% of cases in which some corporation is involved is rather a case where it is a claimant before this court, and then our only question is how must we protect them? Exactly in the same way as individuals... (ECtJ8)

The common sense view - the one that has garnered relative consent-is one wrapped up in the notion of property and the protection of property as an individual right. The concept of property is primordial in capitalist societies and the judicial decision-making process helps to ensure property protections for corporations. This is done by legitimising and producing consent for, amongst other things, corporate protections and benefits. The notion that in order to create and protect jobs, corporations must be protected is put into action through the courts and judicial decisions that then guarantee a certain number of rights to corporations, and even expand upon those rights (such as in the case of giving human rights to corporations). Thus, whilst there may not be a consensus from the general public around corporate rights-indeed many people are not even aware that corporations have human rights! - consent around the notion of protecting private property provides judges with a certain legitimacy to interpret the laws in order to guarantee protections for the capitalist regime of accumulating wealth.

In advanced neoliberal capitalism, the law is an active arm of the state that plays an important role in producing stability and predictability as key components of the market. At the ECtHR, the Court has played a key role in producing and safeguarding the stability of the market. This emphasis has meant that the Court, which addresses civil and political rights, has been extremely reticent to expand upon economic, social and cultural rights which are often considered to be a different order of rights protections (Vasak 1977) and

Footnote 3 continued

procreation. The French government does not allow surrogate pregnancies, so for now the right to procreation assistance techniques will be reserved to lesbian couples and single mothers. 
which often require the consideration of the impact of third parties (i.e. non-state actors) on human rights. Since the ECHR is a traditional, state-centred human rights treaty, private actors cannot be held accountable for human rights violations. In the words of one respondent, “...We [ECtHR judges] should always keep in mind that we are asked only to interpret the provisions of the ECHR no more than that" (ECtJ6). This respondent cautions against interpreting the Convention to widen the scope of European human rights protections to allow for third-party responsibility. But the irony of this statement is that it was a judicial interpretation of the Convention that expanded upon the provisions of the Convention to create corporate human rights. That corporations can now claim their human rights before the ECtHR was therefore a judicial device, not a legislative one (Khoury 2014; Khoury and Whyte 2017; Schwelb 1964). ${ }^{4}$ The judge makes a decision to refrain from issues of corporate accountability, thus engaging a political decision. Noted above, the 'judicialization of politics' has meant that there is a growing reliance on judges to address and 'resolve' core moral problems that affect society. The judgments are in many ways the outcomes of the particular ideologies of the judges, and it is at this juncture that the 'political' and the 'legal' are collapsed. It is at this point that we see the role of the judge as a 'moral and intellectual leader' who takes a decision that contributes to and sustains the hegemony of market-oriented politics. Thus, it is in this context that judges are revealed as pivotal elements in the production of hegemony.

In this respect, the "general activity of law...is wider than purely State and governmental activity and also includes the activity involved in directing civil society, in those zones which the technicians of law call legally neutral, i.e. in morality and custom" (Gramsci 1971, p. 195). Judges possess a form of domination that extends past the courts into the everyday lives of everyday people by inducing submission not only through their coercive powers within the courts, but also through their power to create consent. Judges, as the executors and guarantors of the law, are therefore pivotal in leading society to accept the status quo. Judges uphold the law, which “...operates without 'sanctions' or compulsory 'obligations', but it nevertheless exerts a collective pressure and obtains objective results in the form of an evolution of customs, ways of thinking and acting, morality, etc." (Ibid., p. 242). It is therefore crucial to properly understand the role that judges are playing in the current neoliberal order. Such an understanding requires an analysis of the impact their decisions have in the maintenance of power asymmetries and the advancement of the dominant class hegemony.

\section{Conclusion: Analysing the Judicial Decision-Making Process}

As we have seen, a Gramscian analysis corresponds to the identification of two axes of power: coercion and consent, both of which are necessary for a dominant group to achieve hegemony. Gramsci argued that by ensuring an acceptance and compliance with a dominant set of practices and institutions without having to resort to physical force, the dominant group's beliefs and practices become part of the common sense and thus serve to legitimate the state. This concept is important for understanding how law and legal processes contribute to the hegemony of a dominant social order, but also for constructing a strategy with which to challenge it: a counter-hegemony.

\footnotetext{
4 These authors argue that there is no evidence that the drafters ever meant to include corporations as rightsholders; for an alternative reading of the intention of the drafters of the ECHR, see Emberland (2006).
} 
In this article, we have applied a Gramscian analytical framework to deconstruct the role of judicial actors in our society. The bias and contradictions of law and courts are not accidental but are inherent to the architecture of the neoliberal legal system. Law is not a neutral instrument; it is a product of fundamental asymmetries of power in society. As such, even when the law can be mobilised by subaltern forces through strategic uses of law, it operates in ways that ultimately preserve neoliberal capitalism. We have argued that the neoliberal process and the 'judicialization of politics' have shaped the role of judges in capitalist societies. In the case of the PBA, judges have lost their leadership and become 'technicians of repression'. On the other hand, judges from supranational courts have become 'moral and intellectual leaders' that impose an hegemonic set of values that enable the reproduction of the neoliberal order through the veil of a human rights discourse. The concepts of 'technicians of repression' and 'moral and intellectual leaders' provide the sociolegal researcher with an epistemologically-grounded perspective for studying the decision-making process. In the tradition of critical sociolegal studies, this article has argued that there is no 'neutrality' in decision-making. Despite their individual characteristics and differences, judicial actors are part of a particular 'class' that, by the very virtue of the role that they perform in society, 'lead' society by producing and reproducing the values of the state in their interactions and judgments. Perhaps one of the most important consequences of treating law as a social relation is the capacity to express its fluidity without losing sight of its regularities, i.e. the enabling role that the law plays in the production and reproduction of a particular social, economic, cultural, and political order.

The application of a Gramscian approach to the study of courts and particularly judges is valuable because both are close to, yet distinct from the state; both transmit important ideological values (Hunt 1985; Althusser 1971). Judicial outcomes cannot be understood simply as the manipulation of law by the ruling class (Sweezy 1942; Bourdieu 1986). The analysis of the judicial decision-making process must rather be understood as both driven by and seeking to produce hegemonic values. The individual perspectives of judges must be scrutinised in relation to the dominant economic and political ideology, meaning firstly, that the agency of legal actors should be taken seriously when analysing judicial outcomes; and secondly, any investigation into these actors must take into consideration the dominant social order.

We propose that the Gramscian analytical framework developed in this article can inform a methodological approach to pursuing empirical research into the judicial decision-making process. It is particularly suitable to critical qualitative research into courts, deserving of the design of a critical methodology, which we are currently working upon. Critical research into the judicial decision-making process can illuminate the specific role judicial actors play in the maintenance or disruption of the neo-liberal hegemonic project. The acts of raising questions, observing daily interactions, and showing interest in the perspectives of these actors can serve to demystify the judicial environment. These research techniques allow the researcher to reflect upon judicial assumptions, and the role of the judiciary and courts in our societies. Judicial actors do not merely wield law as an 'instrument'; rather law is understood as a relationship that is produced by the interactions of these actors between themselves and with non-legal actors. By understanding the overarching structures of (formal) law we can also identify spaces of resistance within these complexes of power. 
Acknowledgments Many thanks to Bart Van Klink, Julija Sardelic and Emmanuelle Khoury for comments on earlier drafts of this article. We would also like to thanks the anonymous reviewers for their insightful comments. We are especially grateful to Dave Whyte for many the thought provoking discussions on Gramsci and Poutlantzas, and also for reading and commenting several draft versions of this article. All errors are our own.

\section{Compliance with Ethical Standards}

Conflict of interest The authors declare that they have no conflict of interest.

Open Access This article is distributed under the terms of the Creative Commons Attribution 4.0 International License (http://creativecommons.org/licenses/by/4.0/), which permits unrestricted use, distribution, and reproduction in any medium, provided you give appropriate credit to the original author(s) and the source, provide a link to the Creative Commons license, and indicate if changes were made.

\section{References}

Althusser, L. (1971). Ideology and ideological state apparatuses (B. Brewer, Trans.). In Lenin and philosophy and other essays (pp. 127-186). New York: Monthly Review Press.

Asthana, A., \& Mason, R. (2017). UK must leave European convention on human rights, says Theresa May. The Guardian, Online Edition (25 April). https://www.theguardian.com/politics/2016/apr/25/uk-mustleave-european-convention-on-human-rights-theresa-may-eu-referendum.

Bieler, A., \& Morton, A. D. (Eds.). (2014). Images of Gramsci: Connections and contentions in political theory and international relations. London: Routeledge.

Bourdieu, P. (1986). The force of law: Toward a sociology of the juridical field. The Hastings Law Journal, $38,805-852$.

Brown, W. (2003). Neo-liberalism and the End of Liberal Democracy. Theory and Event, 7(1), Project MUSE. doi:10.1353/tae.2003.0020.

Buckel, S. (2011). The juridical condensations of relations of forces: Nicos poulantzas and law. In A. Gallas, L. Bretthauer, J. Kannankulam, \& I. Stützle (Eds.), Reading poulantzas. Pontypool: The Merlin Press.

Carlen, P. (1976). Magistrates' justice. London: Martin Robertson.

Carrington, K., Hogg, R., \& Sozzo, M. (2016). Southern criminology. British Journal of Criminology, 56(1), $1-20$.

Chambliss, W. (1993). On lawmaking. In W. Chambliss \& M. Zatz (Eds.), Making law: The state, the law, and structural contradictions. Bloomington: Indiana University Press.

Chambliss, W., \& Seidman, R. (1971). Law, order, and power. Massachusetts: Addison-Wesley.

Ciocchini, P. (2013). Tiempo de Justicia: Un análisis de los cambios ocurridos en pos de erradica la demora judicial en la administración de justicia penal bonaerense, Thesis (Unpublished doctoral thesis) Universidad del País Vasco, Donostia - San-Sebastian, Basque Country (Spain).

Ciocchini, P. (2014). Campaigning to eradicate court delay: Power shifts and new governance incriminal justice in Argentina. Crime, Law and Social Change, 61(1), 61-79.

Cox, R. W. (1983). Gramsci, hegemony and international relations: An essay in method. Millennium Journal of International Studies, 12(2), 162-175.

Cutler, A. C. (2005). Gramsci, law and the culture of global capitalism. Critical Review of International Social and Political Philosophy, 8(4), 527-542. (Special Issue: Gramsci and International Relations Theory).

Emberland, M. (2006). The human rights of companies: Exploring the structure of ECHR protection. Oxford: Oxford University Press.

Feeley, M. (1992). The process is the punishment: Handling cases in a lower criminal court. New York: Russell Sage.

Fitzpatrick, P. (1992). The mythology of modern law. New York: Routledge.

Garland, D. (2001). The culture of control. Oxford: Oxford University Press.

Glasbeek, H. (2005, 30 August). War on shareholders. Canadian Dimension. http://canadiandimension.com/ articles/1903. Accessed May 26, 2016.

Gramsci, A. (1971). Selections from the prison notebooks. In Q. Hoare \& G. N. Smith (Eds. \& Trans.) (2005). New York: International Publishers.

Granfield, R. (1986). Legal Education as Corporate Ideology: Student Adjustment to the Law School Experience. Sociological Forum, 3, 514-523. 
Hall, S., Critcher, C., Jefferson, T., Clarke, J., \& Roberts, B. (1978). Policing the crisis: Mugging, the state, and law and order. London: Macmillian Press.

Harrington, C. B., \& Yngvesson, B. (1990). Interpretive sociolegal research. Law \& Social Inquiry, 15(1), 135-148.

Hirschl, R. (2004). Towards juristocracy. Cambridge, MA: Harvard University Press.

Hirschl, R. (2008). The judicialization of mega-politics and the rise of political courts. Annual Review of Political Science, 11, 93-118.

Hirschl, R. (2011). The judicialization of politics. In R. E. Goodin (Ed.), The oxford handbook of political science. Oxford: Oxford University Press.

Hunt, A. (1985). The ideology of law: Advances and problems in recent applications of the concept of ideology to the analysis of law. Law \& Society Review, 19(1), 11-38.

Hunt, A. (1993). Explorations in law and society: Towards a constitutive theory of law. New York: Routledge.

Indermaur, D., \& Roberts, L. (2009). Confidence in the Criminal Justice System. Trends \& Issues in Crime and Criminal Justice, 387, 1-6.

Jessop, B. (1990). State theory: Putting states in their place. Cambridge: Polity Press.

Kennedy, D. (1982a). Antonio Gramsci and the legal system. ALSA Forum, VI(1), 32-37.

Kennedy, D. (1982b). Legal education as training for hierarchy. Journal of Legal Education, 32(4), 591-615.

Khoury, S. (2014).(Transnational) Corporations and Human Rights: an exploration into the accommodation of capital ininternational human rights law, Thesis (Unpublished doctoral thesis) Università degli Studi di Milano, Milan,Italy / Universidad del País Vasco, Donostia - San-Sebastian, Basque Country (Spain).

Khoury, S. \&Whyte, D. (2017). Corporate human rights violations: Global prospects for legal action. Abingdon:Routledge.

Kostewein, E. (2015). Prisión preventiva: entre los medios de comunicación y las autoridades políticas. Revista Direito e Práxis, 6, 54-79.

Litowitz, D. (2000). Gramsci, hegemony, and the law. Brigham Young University Law Review, 2000(2), $515-551$.

Levitt, S. (2004). Understanding why crime fell in the 1990s: Four factors that explain the decline and six that do not. The Journal of Economic Perspectives, 18(1), 163-190.

Loucaides, L. (2007). The European convention on human rights: Collected essays. Leiden: Martinus Nighoff Publishers.

N/A. (2009, 7 April). Lord Hoffmann in all-out attack on European Court of Human Rights. Solicitors Journal. https://www.solicitorsjournal.com/news/public/administrative-and-constitutional/lordhoffmann-all-out-attack-european-court-human-righ.

Oyanedel, J. C. (2016). Confianza en la justicia y la policía en América Latina: Análisis de los efectos de las reformas procesales penales (1995-2013), Revista del CLAD Reforma y Democracia, 64, 141-164.

Poulantzas, N. (2000). State, power, socialism. London: Verso.

Poulantzas, N. (2008). The poulantzas reader, marxism, law, state. J. Martin (Ed.). London: Verso.

Pratt, J. (2007). Penal populism. London: Routledge.

Quinney, R. (1980). Class, state and crime (2nd ed.). New York: Longman.

Santos, B. D. S. (2002). Toward a new legal common sense: Law, globalization and emancipation (2nd ed.). London: Butterworths/LexisNexis.

Sarrabayrouse, M. J. O. (2004) La justicia penal y los universos coexistentes. Reglas universales y relaciones personales. In S. Tiscornia (comp.), Burocracias y violencia. Estudios de antropología jurídica (pp. 203-242). Buenos Aires: Antropofagia.

Schwelb, E. (1964). The protection of the right of property of nationals under the first protocol of the European convention on human rights. The American Journal of Comparative Law, 13(4), 518-541.

Simon, J. (2007). Governing through crime: How the war on crime transformed American democracy and created a culture of fear. Oxford: Oxford University Press.

Stanley, C. (1988). Training for the hierarchy reflections on the British experience of legal education. Law Teacher, 22(2-3), 78-86.

Strinati, D. (1995). An introduction to theories of popular culture. London: Routledge.

Sweezy, P. M. (1942). The theory of capitalist development: Principles of marxian political economy. London: Dennis Dobson Ltd.

Terris, D., Romano, C. P. R., Cesare, P. R., \& Swigart, L. (2007). The international judge: An introduction to the men and women who decide the world's cases. Walatham (Mass.): Brandeis University Press. 
Vasak, K. (1977). Human rights: A thirty-year struggle: The sustained efforts to give force of law to the universal declaration of human rights. UNESCO Courier, 30, 11. (Paris: United Nations Educational, Scientific, and Cultural Organization).

Voeten, E. (2007). The politics of international judicial appointments: Evidence from the European Court of Human Rights. International Organization, 61(4), 669-701.

Wasserfallen, F. (2010). The judiciary as legislator? How the European Court of Justice shapes policymaking in the European Union. Journal of European Public Policy, 17(8), 1128-1146.

Yngvesson, B. (1985). Legal ideology and community justice in the clerk's office. Legal Studies Forum, $9(1), 71-87$.

\section{Cases cited}

Brown v Board of Education, [1954] 347 U.S. 483.

Edwards v Canada (Attorney General) [1930] AC 123, 1 DLR 98 (PC) Lord Sankey.

Gabriela Perozo et al. v Venezuela (Judgment 28 January 2009) Inter-Am. Ct. H.R. (Ser. C) No. 194. 